\title{
A Simplified Strengthening Methodology for Minaret Structures in Turkey: Hagia Sophia Case
}

\author{
Kasım A. Korkmaz
}

Eastern Michigan University, School of Visual and Built Environments, Ypsilanti, MI, USA

\begin{abstract}
Considering various types of historical buildings in Turkey, mosqs are the most common ones. Mosqs have minaret structures standing along next to the main body with dome. The minaret buildings with their own architectural and structural characteristics, are representing the cultural and historical change in different periods over the centruies. Minarets from Ottomon period are the most widespread ones in Turkey. With its cultural synthesis through out the history, minarets from Ottomon period differ from the others with structural capability. Since Turkey is a earthquke prone country, it is very important to make existing historical structures stronger against to the seismic loads. Recently, historical structures have been strengthened with fiber reinforced polymer (FRP) composites. There are numerous of research studies are available related with strengthening using FRP composites. From this standing point, in this research, a simplified and practicale strengthening methodlogy is proposed. For the investigation Hagia Sophia Minaret structures has been used as a case study. In the analysis part, Hagia Sophia Minaret structures have been investigated through time history analyses before and after FRP composite strengthening. As a result of the present research work, displacements and stress values are determined for comparison of the structural behavior of minaret structures.
\end{abstract}

Keywords: Historical buildings, hagia sophia, minaret structures, strengthening, time history analysis.

\section{INTRODUCTION}

In Turkey, Minaret structures have been constructred as taller and slender tower structures with unique structural characteristics and they were constructed as standing along next to the main body with dome. Minaret structures are constructed by using local natural constructional material. They were generally constructed by using solid brick masonry or stone blocks. Baked clay brick units were less frequently used in masonry minarets [1]. Many historical minaret structrues are existing in Turkey from Seljuk and Ottoman periods. Minaret structures are fragile structures with empty circular cross sections through out their heights. They can get damage with the external forces such as seismic forces and even wind forces. Therfore, it is important to make them stronger against lateral loads to cary them to future generations. Stone, brick and Horasan mortar have been used for the construction of minaret structures $[2,3]$. Horasan mortar is an important investigation at that era obtained by mixing crushed brick particles, lime and sand with water [2]. Height, diameter and delicacy of minaret structures are of significant importance. The minaret structures are composed from different parts.

As seen in Figure 1, end ornament is the top part carrying the crescent. Spire is the one of the top parts

*Address correspondence to this author at the Eastern Michigan University, School of Visual and Built Environments, Ypsilanti, MI, USA; Tel: 734-487-2492; E-mail: kkorkmaz@emich.edu after end ornament and cone part is the section in the form of cone. The upper part of the minaret comes top on the main body. Main body is composed of staircase in the form of wall and spiral. Pedestal part is at the bottom and formed by cube and tribune. Tribune is the part which transfers the effects from the cube to the foundation [4].

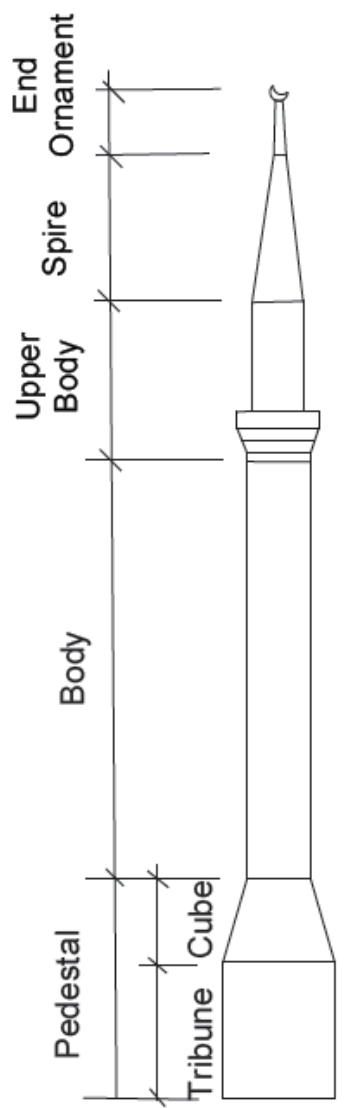

Figure 1: Parts of minarets [4]. 
The minaret structures are distributing the load along with the height of their masses and rigidities of the minarets $[5,6]$. To determine their seismic behaviors of minaret structures, various methods have been used in the literature. Finite element method, modal analysis method, and time history analysis are the most common ones. In the literature various research work is available. Some of them are summarized here to understand the current state for minaret structures and their earthquake performances.

Ertek [4] has investigated minarets and their materials from Ottoman period. He modelled the minarets with finite elements method and compared the minaret structures' behavior with different construction materials. Kusuzumu [7] classified the minaret structures according to the varieties, material, number and positions in plan by addressing the Istanbul minarets. He explained today's restoration methods and techniques by considering Istanbul minarets. Oliveira et al. [8] examined the Hagia Sophia, Suleymaniye, Akbiyik, Mihrimah, Rustem Pasha, Sehzade mosq minarets which are very important cultural values. These minaret structures are the most well known ones all over the country. These structures were modelled with finite element method. Frequency and stress values were obtained by using modal superposition approach. Altunisik [9], modelled minaret structures with ANSYS. In his research, Iskenderpasa minaret located in Trabzon, Turkey was strengthen with fiber reinforced polymer (FRP) composite. He carried out dynamic analysis of minaret and compared the values from before and after strengthening. Sener [10] examined a historical masonry minaret which is located in Hasankeyf, East part of the country and developed a new methodology for preventation of integrity of historical structures. Turk and Cosgun [11] examined the dynamic behavior of a historical mosq minaret in Istanbul, Turkey and proposed a seismic strengthening method by using FRP composites.

In the present study, based on the existing literature, a simplified strengthening methodlogy is proposed. Hagia Sophia Minaret structure was considered as a case study and strengthened with FRP composite. In the study, behavior of the minaret structure has been compared with before and after strengthening with FRP composite. In the analysis, time history analysis was carried out. As a result of time history analyses, displacements and stress values were determined for comparison. Considered minaret structures were strengthen with FRP composite for the purpose of increasing the earthquake resistance of historical minaret structures. To compare the behavior of the minaret's structure before and after strengthening, dynamic time history analyses were performed. The displacement and stress values of historical minarets were determined. In the time history analysis, as an earthquake, Kocaeli earthquake as one of the devistating earthquakes hit Turkey in 1999 was considered in the study and its ground motion was applied on the minaret structures through out the time history analysis to investigate the structural behavior of the minaret structures.

\section{HAGIA SOPHIA MINARET STRUCTURES}

Hagia Sophia was constructed in Istanbul, Turkey by Justinianus in 532-537. The structure is considered as one of the oldest monuments existing in the world. This structure partially damaged in the past earthquakes and were again repaired and stregnthened [12]. Hagia Sophia is presented in Figure 2 [13].

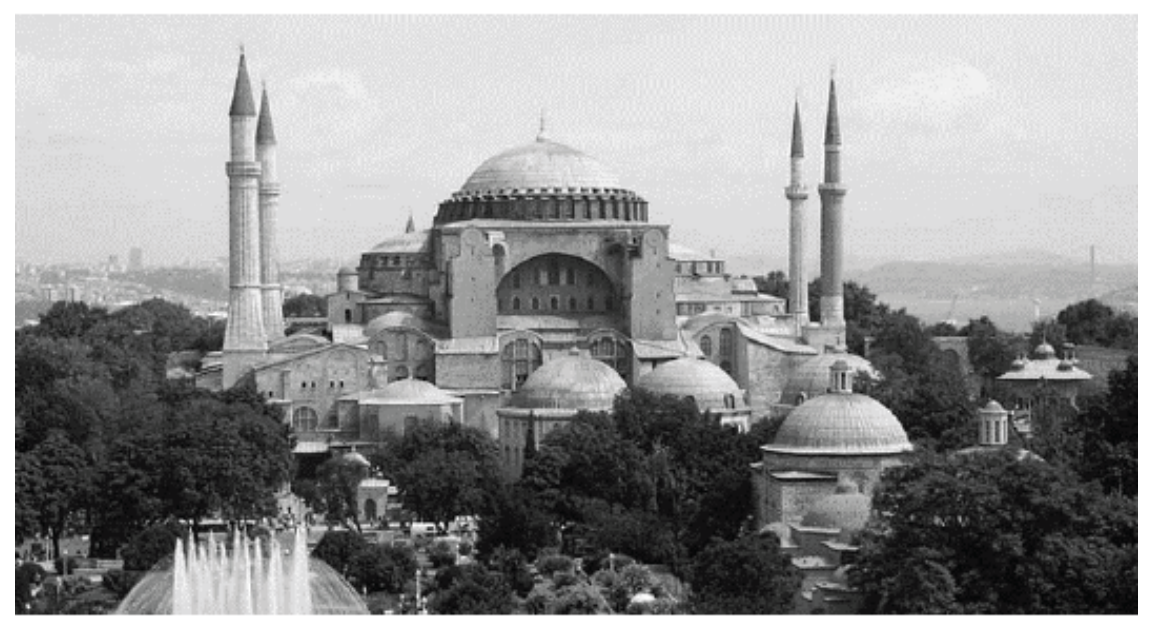

Figure 2: Hagia Sophia View [13]. 
Hagia Sophia was restored several times during the Ottoman period. Hagia Sophia faced with collapsing in the years of 1566-1574, and two piers was added to the north face of the structure to strengthen the structure. In between years of 1703-1730, another major repair was conducted for strengthening of the building. Up to now, the building has been repaired and strengthened several times [12].

There are 4 minarets with different heights next to main body of Hagia Sophia. These minarets have been constructed in different centuries and their heights, wall thicknesses and diameters are different. Three of them were constructed with stone and the thinnest one in the southeast corner and two minarets in the west part. One of these was built with brick material. They are at the same geometry feature. Hagia Sophia minaret models are given in Figure 3 and the dimensions of the minarets are represented in Table 1. Stone was used in model 1, 2 and 3, and the brick material was used in model 4. The material properties are given in Table 2.

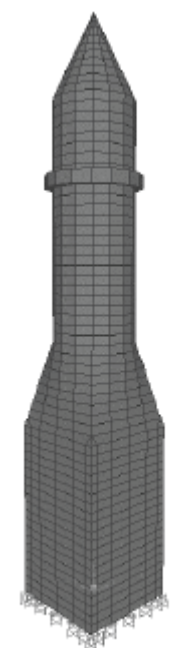

Model 1-2

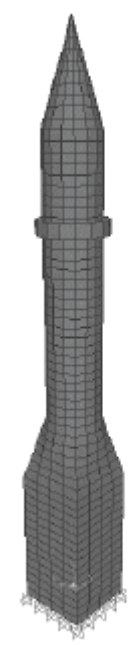

Model 3

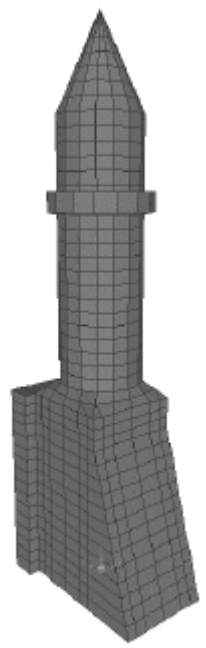

Model 4
Figure 3: Minarets of Hagia Sophia.

Table 1: Properties of Hagia Sophia Minarets

\begin{tabular}{|c|c|c|c|}
\hline & $\begin{array}{c}\text { Hagia } \\
\text { Sophia } \\
\text { Model 1-2 }\end{array}$ & $\begin{array}{c}\text { Hagia } \\
\text { Sophia } \\
\text { Model 3 }\end{array}$ & $\begin{array}{c}\text { Hagia } \\
\text { Sophia } \\
\text { Model 4 }\end{array}$ \\
\hline \hline $\begin{array}{c}\text { The total height } \\
\text { of minarets }\end{array}$ & 66.55 & 63.20 & 44.96 \\
\hline $\begin{array}{c}\text { Number of } \\
\text { balconies }\end{array}$ & 1 & 1 & 1 \\
\hline Body height & 37.90 & 39.70 & 33.60 \\
\hline $\begin{array}{c}\text { Wall } \\
\text { thickness (m) }\end{array}$ & 1.00 & 0.55 & 0.85 \\
\hline Body Diameter & 4.70 & 3.10 & 3.30 \\
\hline
\end{tabular}

Table 2: Material Properties used in the Modeling [14]

\begin{tabular}{|c|c|c|c|}
\hline $\begin{array}{c}\text { Materials } \\
\text { Type }\end{array}$ & $\begin{array}{c}\text { Modulus of } \\
\text { Elasticity } \\
\text { (Mpa) }\end{array}$ & $\begin{array}{c}\text { Poisson } \\
\text { Ratio }\end{array}$ & $\begin{array}{c}\text { Tensile Strength } \\
\text { (Mpa) }\end{array}$ \\
\hline \hline Brick & 3000 & 0.2 & - \\
\hline $\begin{array}{c}\text { Stone walls } \\
\text { (Limestone) }\end{array}$ & 26000 & 0.2 & - \\
\hline FRP & 240000 & 0.22 & 3800 \\
\hline
\end{tabular}

Kocaeli Earthquake ground motion as defined in Table $\mathbf{3}$ and in Figure $\mathbf{4}$ was selected as the earthquake data to investigate the structural behavior of the minaret structurres through out time history analysis. The displacement and stress values of the minaret structures were determined as a result of time history analysis. Obtained values in $X$ and $Y$ direactions are same due to the symety in the geometry.

\section{STRENGTHENING HAGIA SOPHIA MINARETS}

FRP systems give quite good results against to the cyclic loading and recently, FRP systems have been used as an alternative solution in strengthening from outside of the existing reinforced concrete and masonry buildings. It is also becoming a good solution for historical buildings $[11,15]$.

From this standing point, in the present study, fiber reinforced polymer (FRP) systems are used for improving the structural behavior against to the seismic loads. The historical minarets were modelled with SAP 2000 software in 3-D. Shell elements were used in the course of the modelling. In strengthening, layered shell elements for presenting the FRP systems were used. Layered shell elements consist of many elements which has different thickness and the desired properties of the material can be assigned to the various layers. Strengthening FRP systems have been represented in the form of multi layers. Layered shell elements contain the important properties such as layer thickness, layer distance, material angle. Layered shell element and shell element are shown in Figure 5 [15].

\section{ANALYSIS RESULTS}

In this study, Hagia Sophioa minarets which are in different dimensions have been examined by using dynamic time history analysis by using the selected ground motion record as Kocaeli Earthquake. Minaret structures were strengthened and structural behavior of 
Table 3: Ground Motion Records

\begin{tabular}{|c|c|c|c|c|c|c|}
\hline Earthquake & Date & $\begin{array}{c}\text { Moment } \\
\text { Magnitude } \\
(\mathbf{M w})\end{array}$ & Record & $\begin{array}{c}\text { Ground } \\
\text { Velocity } \\
\text { (cm/s) }\end{array}$ & $\begin{array}{c}\text { Ground } \\
\text { Acceleration } \\
(\mathbf{g})\end{array}$ & $\begin{array}{c}\text { Epicenter } \\
\text { Distance } \\
\mathbf{( k m )}\end{array}$ \\
\hline \hline Kocaeli & $17 / 08 / 1999$ & 7.4 & SKR090 & 79.5 & 0.376 & 3.1 \\
\hline
\end{tabular}

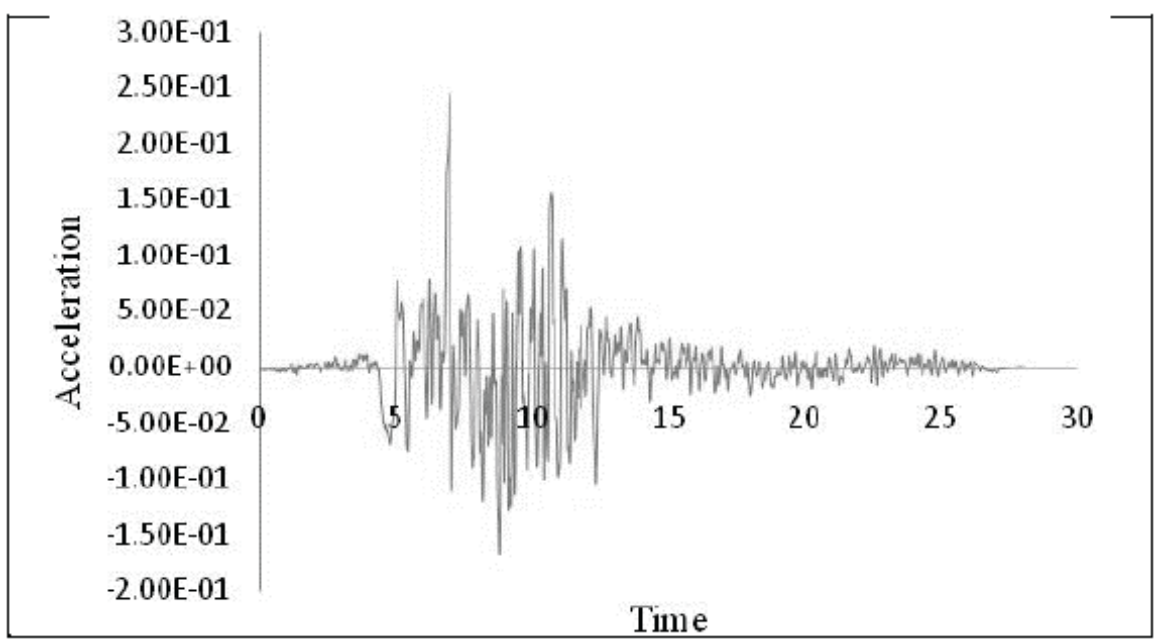

Figure 4: Time-dependent acceleration graph of 1999 Kocaeli earthquake.
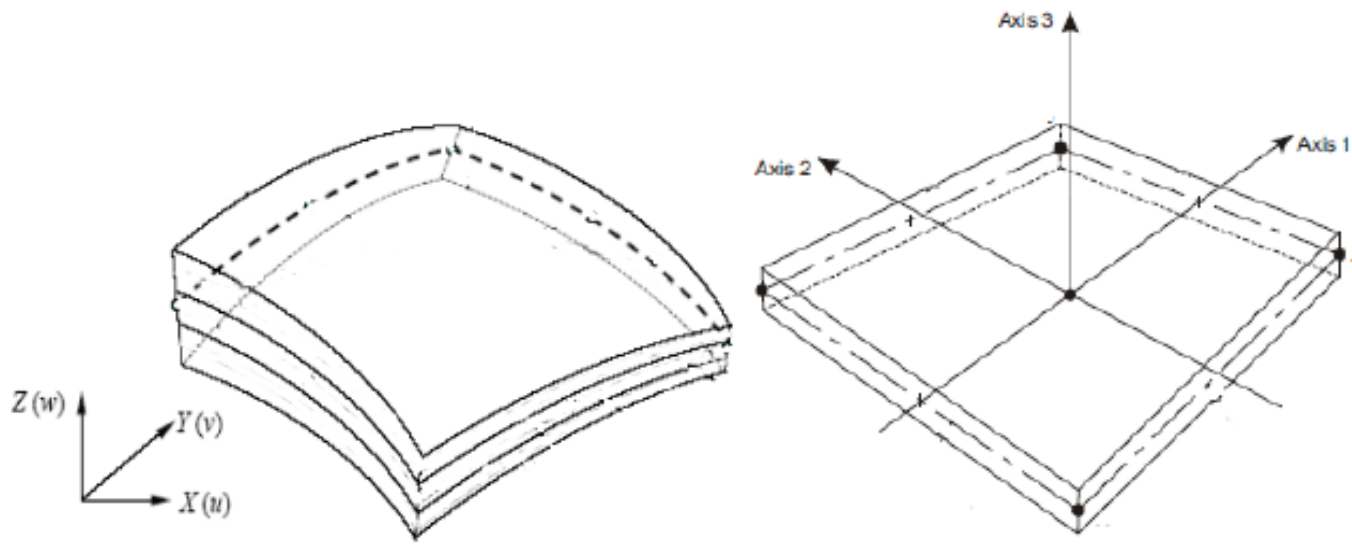

Figure 5: Layered shell elements [14].

minarets were compared before and after strengthening.

As a result of the analysis, periods, mode shapes, displacements and stresses were determined and the values of before and after strengthening of Hagia Sophia Minarets were compared. Since the minaret structures are symmetrical in geometry, obtained values from the analysis at $X$ and $Y$ direction are identical. The period values and mode shapes obtained from the analysis results are shown in Table 4 and Figure 6. The stress and displacement values obtained are given in Figures $\mathbf{7}$ and $\mathbf{8}$ and the stress shapes of modells are given in Figure $\mathbf{9}$.
In Hagia Sophia minarets, the maximum displacement occurs $34 \mathrm{~mm}$ in Minaret 3. The displacement obtained at Kocaeli Earthquke is $28 \mathrm{~mm}$. The stress value before strengthening in Kocaeli Earthquake is 5MPA, the value of stress after strengthening is 3 MPA. The lowest displacement values of the historical minarets were occurred in Minarets 1 and 2 . The highest stress values were occured in Minarets 1 and 2. The highest displacement was performed in Minaret 3. Material properties of these 3 minarets are the same. The heights of the Minaret 1 and 3 are quite close. The thickness of wall of the Minaret 3 is $0.55 \mathrm{~m}$, the wall thickness of the Minaret 1 is $1.0 \mathrm{~m}$. The body diameter of Minarets 1 
Table 4: Period Values Obtained from Base and Strengthen Models

\begin{tabular}{|c|c|c|c|c|c|c|}
\hline Periods & $\begin{array}{c}\text { Model 1-2 } \\
\text { Base }\end{array}$ & $\begin{array}{l}\text { Model 1-2 } \\
\text { Strengthen }\end{array}$ & $\begin{array}{l}\text { Model } 3 \\
\text { Base }\end{array}$ & $\begin{array}{c}\text { Model } 3 \\
\text { Strengthen }\end{array}$ & $\begin{array}{c}\text { Model } 4 \\
\text { Base }\end{array}$ & $\begin{array}{c}\text { Model } 4 \\
\text { Strengthen }\end{array}$ \\
\hline $\mathrm{T}_{1}$ & 0.385926 & 0.317697 & 0.524764 & 0.384923 & 0.632392 & 0.297977 \\
\hline $\mathrm{T}_{2}$ & 0.385879 & 0.317647 & 0.524113 & 0.384455 & 0.582459 & 0.289682 \\
\hline $\mathrm{T}_{3}$ & 0.105874 & 0.087999 & 0.127755 & 0.094705 & 0.199586 & 0.127331 \\
\hline $\mathrm{T}_{4}$ & 0.105856 & 0.087979 & 0.127489 & 0.094505 & 0.164362 & 0.102557 \\
\hline
\end{tabular}

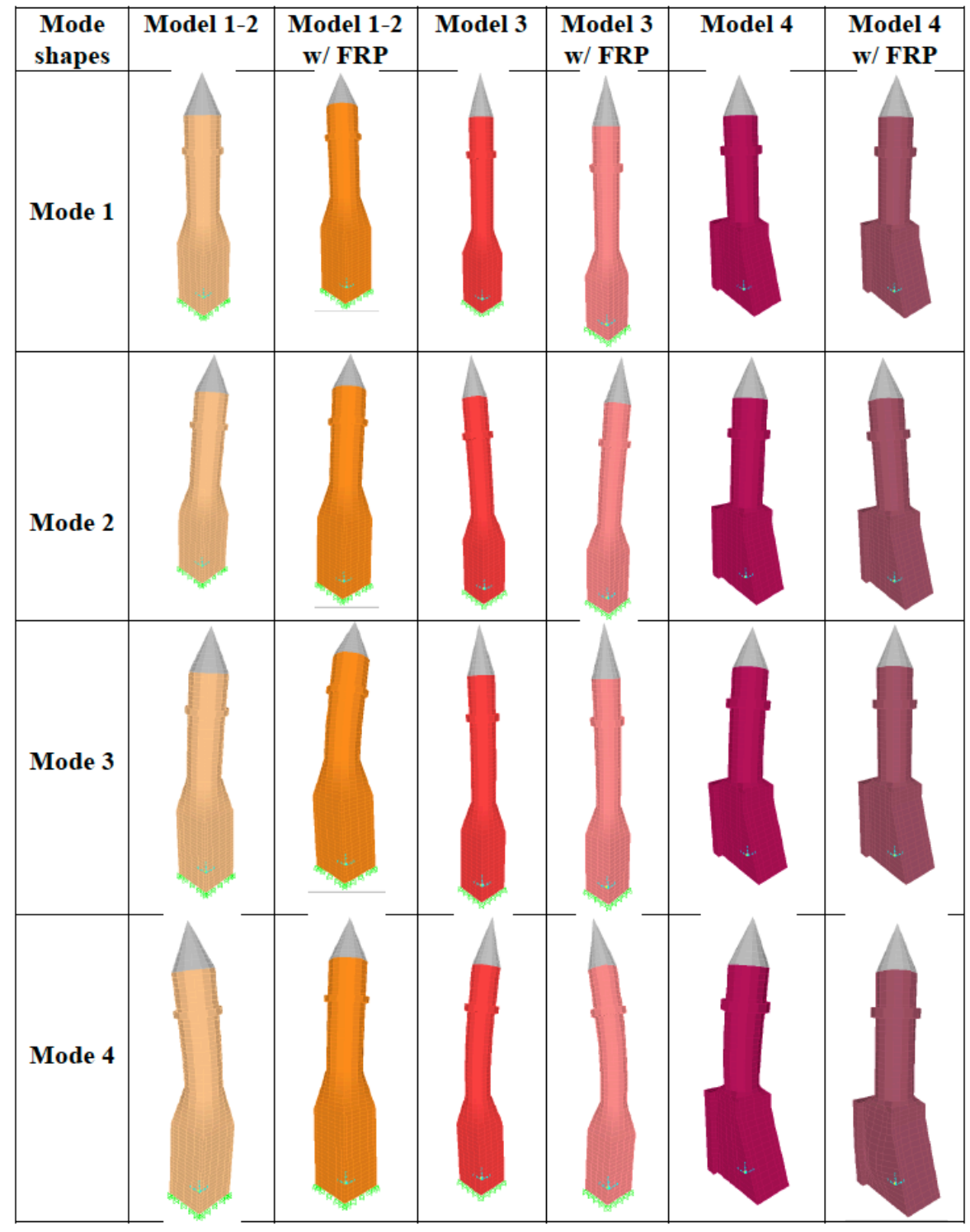

Figure 6: Mode shapes obtained from dynamic analysis.

and 2 is $4.7 \mathrm{~m}$, of Minaret 3 is $3.10 \mathrm{~m}$. Minaret 3 is thinner than the Minaret 1 and 2. The difference in displacement and stress can be resulted from the variations of these dimensions. The height of the Minaret 4 is lower than the Minarets 1 and 2, in addition to, the thickness and body dimensions are smaller.
Therefore, Minaret 4 has bigger displacement and lower stress performed. Height of the minarets effect the displacement and stress values. However, the body diameter also effects the results. If the wall thickness is more and the radius is greater in the same height, the minaret strcuture is more durable. 

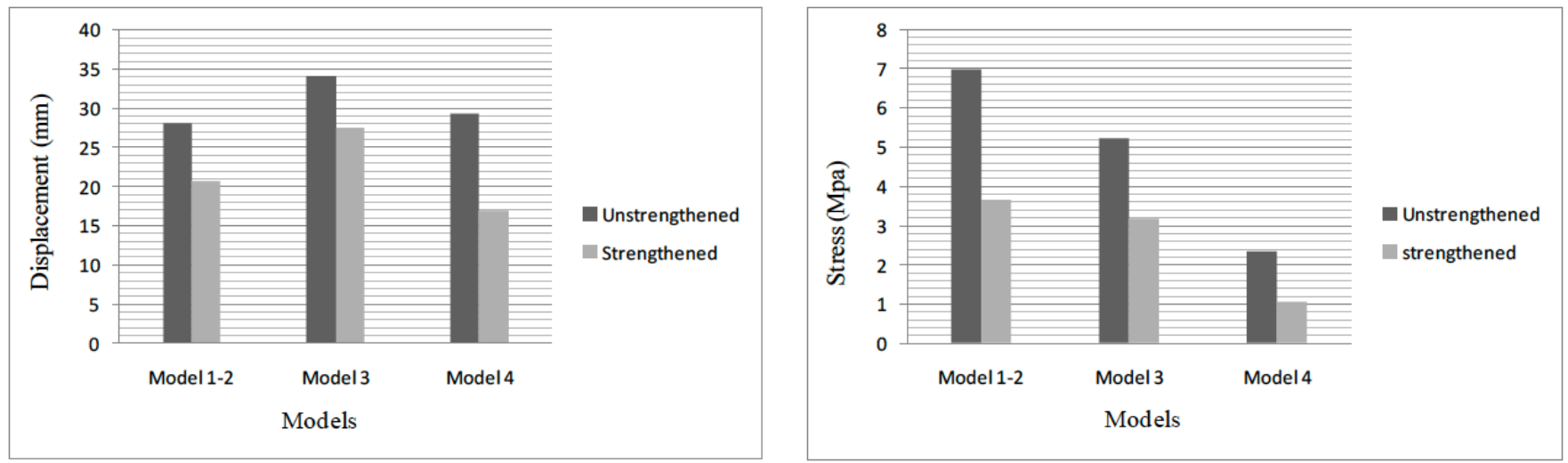

Figure 7: Displacement values obtained from dynamic analysis. Figure 8: Stress values obtained from dynamic analysis.

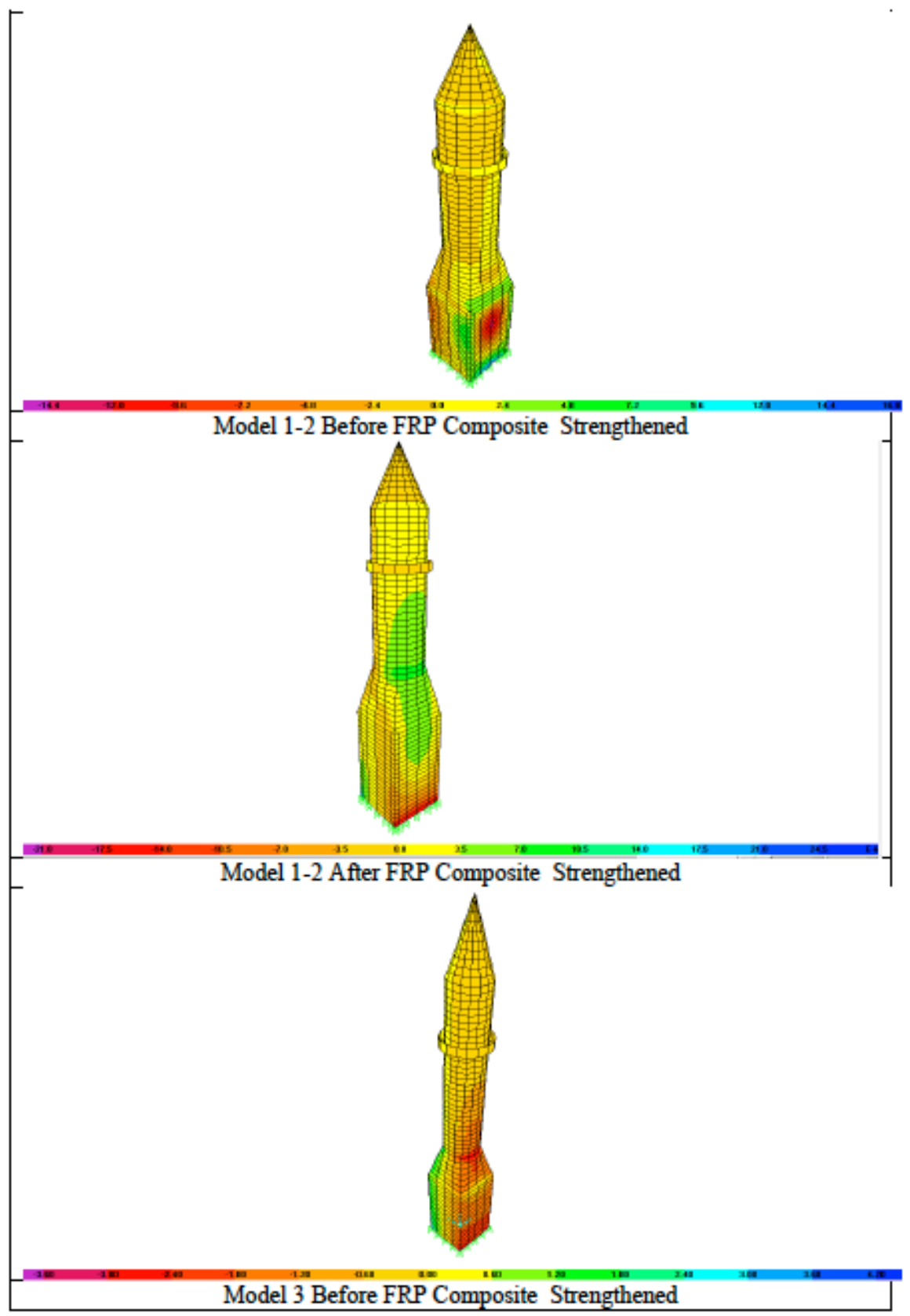

Figure 9: Stress distributions for minaret models. 


\section{CONCLUSION}

For minaret structures in Turkey, stone and brick masonry materials are the major structural elements for centruies. Cut stone blocks have been used to construct them. Recent Turkish earthquakes hit historical structures including minaret structures in Turkey. Therefore, a detailed investigation is neccessary for existing historical monumental structures including minaret structures. In the present study, historical minaret structures were evaluated in detail. As a case study, Hagia Sophia Minaret structures were structurally investigated with seismic loadings. The minaret structures were investigated through time history analyses. After structural definition, a simplified structural strengthening methodology was applied for the minaret stdutures. Structural behavior before and after FRP composite strengthening was investigated. Investigation was done through time history analyses by using Kocaeli earthquake data. As a result of the analyses, displacements and stress values were discussed. As a conclusion, proposed strengthening approach was found applicable and practical for easy application and strcutural improvement.

\section{REFERENCES}

[1] Dogangun A, Acar R, Sezen H, Livaoglu R. Investigation of dynamic response of masonry minaret structures. Bulletin of Earthquake 2008; 6: 505-517. https://doi.org/10.1007/s10518-008-9066-5

[2] Erdogan ST, Erdoğan TY. Ten thousand year history of binder materials and concrete. ODTÜ publishing house, Ankara 2007b.
[3] Dogangun A. Performance of reinforced concrete buildings during the May 1, 2003 Bingol earthquake in Turkey. Eng Struct 2004; 26: 841-856. https://doi.org/10.1016/j.engstruct.2004.02.005

[4] Ertek E. Structural Modeling and Earthquake Analysis of Ottoman Minarets. Graduate school of Natural and applied Sciences, Gebze 2009.

[5] Chopra AK. Dynamics of Structures: Theory and application to earthquake engineering, Prentice, Inc., New Jersey 1995.

[6] Dogangun A, Sezen H, Tuluk Ol. Traditional Turkish masonry minarets and their earthquake damage. Int $\mathrm{J}$ Archit Heritage: Conserv Anal Restor 2007a; 1: 1-21. https://doi.org/10.1080/15583050701436980

[7] Kusuzumu HK. Traditional construction techniques and the contemporary restorations of Istanbul minarets. Graduate school of Natural and applied Sciences, Mimar Sinan Fine Arts University 2010.

[8] Oliveira CS, Çaktı E, Stengel D, Branco M. Minaret behavior under earthquake loading: The case of historical Istanbul. Earthquake Engineering and Structural Dynamics 2012; 4(1): 19-39. https://doi.org/10.1002/eqe.1115

[9] Altunisik AC. Dynamic response of masonry minarets strengthened with Fiber Reinforced Polymer (FRP) composites. Nat Hazards Earth Syst Sci 2011; 11: 2011. https://doi.org/10.5194/nhess-11-2011-2011

[10] Sener IN. An Innovative methodology and structural analysis for relocation of historical masonry monuments. A case study of Hasankeyf, MSc Thesis METU, Ankara, Turkey 2004.

[11] Turk AM, Cosgun C. Seismic behaviour and retrofit of historic masonry minaret. Građevınar 2012; 64(1): 39-45.

[12] Aydingun SG. The Hagia Sophia Repairs after earthquakes of throughout the history, Kocaeli Earthquake Symposium, Kocaeli, Turkey 2005.

[13] URL_1, 2015 www.ayasofyamuzesi.gov.tr

[14] Kheyroddin A, Saghafi MH, Safakhah S. Strengthening of historical masonry buildings with fiber reinforced polymers (FRP), Advanced Materials Research Conference, 2010. https://doi.org/10.4028/www.scientific.net/amr.133-134.903

[15] Kirlangic AS. Re-evaluatıon of earthquake performance and strengthening alternatives of hagia sophia. Earthquake engineering, Bosporus University 2008.

(C) 2017 Kasım A. Korkmaz; Avanti Publishers.

This is an open access article licensed under the terms of the Creative Commons Attribution Non-Commercial License (http://creativecommons.org/licenses/by-nc/3.0/) which permits unrestricted, non-commercial use, distribution and reproduction in any medium, provided the work is properly cited. 